\title{
Õppija teekond: sarnasuse tunnetamisest sihtkeelepärase kasutuseni
}

\author{
Annekatrin Kaivapalu \\ Turu Ülikooli soome keele professor \\ ajakirja Lähivõrdlusi. Lähivertailuja peatoimetaja \\ kaivapa@tlu.ee
}

\begin{abstract}
Teesid: Artiklis käsitletakse lähtekeele mõju muutemorfoloogia omandamisele. Eesmärk on selgitada, millistel tingimustel viib keeltevahelise sarnasuse tunnetamine sihtkeelepärase keelekasutuseni või mis seda takistab. Vaatluse all on soome keelt õppivate eestikeelsete gümnaasiumiõpilaste valjusti mõtlemise protokollid ja retrospektiivsed intervjuud ning soome algkooli ettevalmistava õppe rühma soome keele kui teise keele tundide spontaanse suulise keelekasutuse lindistused. Uurimuse tulemused osutavad, et lähisugulaskeele morfoloogia õppimisel eelneb süsteemi õppimine elementide õppimisele. Kui õppija on tunnetanud kahe keele morfoloogiasüsteemide sarnasust, teab ta oma emakeele põhjal üldjoontes, kuidas sihtkeele süsteem toimib. Tunnetatud sarnasusele toetumist sihtkeeles võib takistada õppija kartus "liigse" keeltevahelise sarnasuse ees või reeglipõhine õpetus.
\end{abstract}

Märksõnad: eesti keel, keeltevaheline mõju, muutemorfoloogia, teise keele omandamine, tunnetatud keeltevaheline sarnasus, soome keel

\section{Sihtkeele õppimisest, lähtekeele mõjust ja keeltevahelisest sarnasusest}

Keeleõppija on emakeele ja varem õpitud keelte rohkem või vähem kogenud kasutaja. Uut sihtkeelt õppides tugineb ta sellele, mida juba oskab. Nii keelekeskkonnas (teise keele omandamine) kui ka väljaspool keelekeskkonda (võõrkeele omandamine) püüab õppija leida esmajoones keeltevahelist sarnasust, oletades, et iga uus keel toimib üldjoontes samamoodi kui lähtekeel(ed), s.t emakeel ja teised varem omandatud keeled. Tuttavate nähtuste märkamine ning keeltevahelise sarnasuse tunnetamine on esimene samm sihtkeele mõistmise ja omandamise teel.

Kui lähte- ja sihtkeele süsteemid sarnanevad, peab oletus keelte sarnasest toimimisest paika ning lähtekeel avaldab sihtkeele õppimisele positiivset mõju. 
Kui lähte- ja sihtkeele süsteemid erinevad, on mõju negatiivne ja lähtekeelele tuginemine ei vii sihtkeelepärase keelekasutuseni. Mõlemal juhul on tegemist põhiolemuselt sama protsessiga: toimub keeleülekanne.

Teise keele omandamise uurimisloos on enamasti keskendutud lähtekeele mõju negatiivsetele avaldumisvormidele või uuritud lähtekeele mõju eristamata positiivset ja negatiivset tulemust (Kaivapalu \& Martin 2007; Jarvis \& Pavlenko 2008). Samas on keeleõppijad ja -õpetajad siiski alati teadnud ja osa lähtekeele mõju uurijatest (vt nt Ringbom 1987, 2007; Odlin 1989) ka oma pikaajalise tegevuse jooksul järjekindlalt rõhutanud, et õppija emakeelele sarnase keele õppimine läheb kiiremini ja kergema vaevaga kui geneetiliselt või tüpoloogiliselt kaugema keele õppimine. Seetõttu on lähte- ja sihtkeele vahelise sarnasuse aste osutunud üheks paremaks lähtekeele mõju toimimise ennustajaks (Kellerman 1979; Kaivapalu \& Martin 2007; Jarvis \& Pavlenko 2008: 176; Schepens \& van der Slik et al. 2013).

Suhtumine lähtekeele mõjusse on vaheldunud ühest äärmusest teise: täielikust eitamisest kuni arusaamani, et lähtekeele mõju seletab kõik keeleõppija probleemid (Martin 2006). Skeptilisemalt on lähtekeele mõjusse, eriti positiivse mõju võimalikkusesse suhtutud morfoloogia ja morfosüntaksi osas, eriti (muute) morfoloogias, mida on peetud alaks, kus lähtekeele mõju esineb väga harva või üldse mitte (detailsem ülevaade Jarvis \& Odlin 2000). Lähtekeele morfoloogia mõju alahindamine on suures osas põhjustatud asjaolust, et enamik teise keele omandamise uurimustest on keskendunud suurematele indoeuroopa keeltele, kuid nende morfoloogiline süsteem on piiratud. Scott Jarvis ja Terence Odlin (2000) on siiski veenvalt osutanud, et isegi kui silmnähtavat morfoloogilist keeleülekannet ei ilmne, leiavad keeleõppijad lähte- ja sihtkeele morfoloogilistes struktuurides vastavusi. Varasemad vähesed uurimused lähtekeele mõjust morfoloogiale käsitlevad selle negatiivset avaldumisvormi (Duškova 1984; Selinker \& Lakshmanan 1992; De Angelis \& Selinker 2001). Rikka morfoloogiaga lähisugulaskeeltes nagu eesti ja soome keel on ka muutemorfoloogias lähtekeele mõju esmajoones positiivne ning lihtsustab eestlastel soome keele ja soomlastel eesti keele õppimist (Kaivapalu 2005; Kaivapalu \& Martin 2007).

Tänaseks on lähtekeele mõju uurimises kujunenud kaks vastakat suunda. Ühelt poolt on see laienenud uutesse valdkondadesse, mh morfoloogia ja morfosüntaksi omandamisse, ning Scott Jarvise (2000, 2010) võrdluspõhisest lähenemisest inspireerituna muutunud metodoloogiliselt märgatavalt täpsemaks. Lisaks lähtekeele negatiivset mõju käsitlevatele uurimustele on sajandi esimesel kümnendil tähelepanu keskmesse tõusnud lähtekeele positiivne mõju ka seni ignoreeritud morfoloogia valdkonnas (Jarvis \& Odlin 2000; Kaivapalu 2005; Kaivapalu \& Martin 2007). Teisalt on eriti pärast 2010. aastat märgata lähtekeele negatiivset mõju käsitlevate uurimuste ekspansiooni, nagu on tõdenud nt Niclas Abrahamsson (2015). Käesolev artikkel ongi sellest inspireeritud. 
Håkan Ringbomi (1987) ja Terence Odlini (1989) klassikalistest uurimustest alates on püütud välja selgitada, kuidas täpselt lähtekeel sihtkeele omandamist mõjutab. Positiivse mõju vältimatu eeltingimus ning käivitaja on lähte- ja sihtkeele sarnasuse tunnetamine, mida esimesena rõhutas Roger Andersen (1983). Õppijate keeleloomeprotsessi uurimine (Kaivapalu 2005) osutab siiski, et keeltevahelise sarnasuse tunnetamine ei realiseeru alati sihtkeelepärase keelekasutuseni juhtiva lähtekeele positiivse mõjuna. Käeolev artikkel püüab vastata küsimusele, millistel tingimustel tunnetatud keeltevaheline sarnasus viib lähtekeele positiivse mõjuni muutemorfoloogias või mis seda takistab. Analüüs toetub ühelt poolt soome keelt võõrkeelena õppivate eesti emakeelega gümnaasiumiõpilaste valjusti mõtlemise protokollidele ja retrospektiivsetele intervjuudele ning teisalt soome algkooli ettevalmistava óppe rühma soome keele kui teise keele tundide spontaanse suulise keelekasutuse lindistustele. Tähelepanu keskmes on soome keele õppijate keeleloomeprotsess ning seda soodustavad või piiravad tegurid.

\section{Keeleülekande ja keeltevahelise sarnasuse avaldumisvormid}

Artiklis käsitatakse lähtekeele mõju keeleelementide ja keeletöötlusprotsesside (mõistmis- ja keeleloomeprotsessid) ülekandumisena lähtekeelest sihtkeelde. Esimesel juhul on tegemist elemendiülekandega (ingl item transfer), teisel juhul süsteemi ehk protseduurilise ülekandega (system / procedural transfer) (Ringbom 2007: 54-58; Ringbom \& Jarvis 2009: 110; ka Martin 2006; Kaivapalu \& Martin 2007 product ja process transfer). Elemendi- ja süsteemiülekande eristamine võimaldab vastata ühele keeltevahelise mõju uurimise põhiküsimusele: mida õigupoolest üle kantakse.

Elemendiülekandes kanduvad lähtekeelest sihtkeelde konkreetsed keeleelemendid: häälikud, tähed, morfeemid, sõnad, fraasid, lausekonstruktsioonid. Seega on tegemist keeleülekandega produkti tasandil, ülekande tulemus on näha õppija keeleloomes (Kaivapalu \& Martin 2007), kuid selle taustal kulgev protsess jääb sihtkeelepärase keelekasutuse puhul enamasti tundmatuks. Elemendiülekanne eeldab keeleõppija tunnetuses üksühese vastavuse loomist sihtkeele ja lähtekeele elemendi vahel (interlingual identifications, vt Jarvis \& Odlin 2000: 538). Vastavuse loomise aluseks on sellisel juhul keeltevaheline tunnetatud sarnasus (perceived similarity), mis nagu ka oletatav sarnasus (assumed similarity) on erinevalt keelesüsteemide võrdlusel põhinevast tegelikust sarnasusest (actual similarity) õppija individuaalsusest lähtuv psühholingvistiline ilming (üksikasjalikku ülevaadet tegelikust, tunnetatud ja oletatavast sarnasusest vt Kaivapalu \& Martin 2015: 57-58). Tunnetatud sarnasus on eriti 
oluline sihtkeele mõistmisel, oletatav sarnasus aga keeleloomes. Elementidevahelise seose tekkimisel kombineerub konkreetsete keelevormide tunnetatud sarnasus vormi või funktsiooni oletatava sarnasusega. Sihtkeele mõistmise varases faasis seostab õppija sihtkeele elemendi oletatava lähtekeelse vastega ja keeleloomes lähtekeele elemendi sihtkeele elemendiga. Keele mõistmisel on vastavuse identifitseerimise suund sihtkeelest lähtekeelde, keeleloomes aga lähtekeelest sihtkeelde.

Süsteemiülekande all mõeldakse informatsiooni organiseerimise põhimõtete ülekandumist. See avaldub vormide paradigmaatilises (nt vormimoodustusmehhanismid, sõnavormide grammatilised tähendused) ja süntagmaatilises (nt liitsõnade moodustamisreeglid, sõnajärjemallid) organiseerimises ning tähenduse ja vormi seostamise põhimõtetes. Tegemist on protsessiga, mis sihtkeelepärase keelekasutuse korral ei ole õppija keeleloomes enamasti tuvastatav ja on seetõttu palju raskemini uuritav kui elemendiülekanne. Erinevalt elemendiülekandest on süsteemiülekanne võimalik kas emakeelest või mõnest muust väga hästi omandatud keelest, kuid lähtekeele grammatikareeglid ja semantika peavad olema automatiseerunud, et olla süsteemiülekande aluseks.

Sihtkeele omandamine algab lähte- ja sihtkeele elementide sarnasuse tunnetamisest. Elementide ja nende vastavuse omandamine eelneb üldjuhul süsteemide vastavuse omandamisele, mille käigus mh mitmekesistuvad lihtsustatud üksühesed keeltevahelised vastavused. Håkan Ringbom (2007: 98-101) on sihtkeele omandamist käsitlevas mudelis toonud välja järgmised osaliselt kattuvad etapid: 1) elementide õppimine keele mõistmise eesmärgil; 2a) elementide õppimine keeleloome tarbeks; 2b) süsteemi õppimine keele mõistmiseks; 3) süsteemi õppimine keeleloome jaoks. Kõikidel etappidel on lähtekeele mõju oluline, kuid see toimib kõigil neljal juhul veidi erinevalt. Keele omandamise lähtepunkt on elementide õppimine keele mõistmise eesmärgil, mis lähedase sugulaskeele puhul saavutatakse üsna kiiresti. Uurimistulemused näitavad (Kaivapalu 2015), et sihtkeelt õppimata ja keelekeskkonnas viibimata mõistavad eestlased soomekeelsest ja soomlased eestikeelsest kirjalikust tekstist oma emakeelele ja selle variantidele, teistele varem õpitud keeltele ning üldteadmistele tuginedes keskmiselt kolmandiku. Selle etapi kiire ja efektiivne läbimine eristab lähisugulaskeele õppijat muu emakeelega õppijast.

Esimesele etapile järgnevad enam-vähem paralleelselt elementide õppimine keeleloome eesmärgil ja süsteemi õppimine keele mõistmiseks. Viimase käigus õpitakse varasemale üksühesele seosele lisaks tuttava sõnavormi muid grammatilisi ja leksikaalseid tähendusi, kasutuskontekste jm. Järk-järgult täiustub õppija arusaam sellest, kuidas erinevad sihtkeele elemendid vastavad lähtekeele elementidele. Süsteemidevaheliste vastavuste loomine on elementidevaheliste vastavuste loomisest tunduvalt keerulisem, sest täpseid vastavusi esineb kahe keele vahel harva isegi väga lähedastes keeltes. Süsteemi õppimisel 
keele mõistmise eesmärgil mängivad olulist rolli keeltevahelised funktsionaalsed ja semantilised sarnasused ning vormisarnasused jäävad sekundaarseks, sest üldjoontes on tekst mõistetav ka ilma muutetunnuste täpse analüüsita. Küll aga mängib keeleloomes olulist rolli vormide sarnasus, kus grammatilist tähendust väljendava elemendi puudumine või vale kasutamine võivad põhjustada arusaamatusi teksti mõistmisel.

Nii elemendi- kui ka süsteemiülekandel on lähedaste sugulaskeelte puhul enamasti sihtkeelepärase keelekasutuseni viiv positiivne efekt: eriti oluline on siin analoogia. Dorothea Möhle ja Manfred Raupach (1989: 202) määratlevad analoogiapõhist keeleülekannet kui protsessi, mille käigus kuulaja või kõneleja aktiveerib, mõistab ja väljendab ühe tunnetuspiirkonna teadmist teise, analoogilise tunnetuspiirkonna või -struktuuri kaudu. Seejuures eristavad nad 1) mälujälgede või tegevuse ülekannet, 2) üldistamist ehk tegevuste laiendamist uute elementidega ja 3) informatsiooni ülekannet ühest valdkonnast teise probleemi lahendamiseks. Mistahes lähtekeele elemendi või protsessi ülekannet sihtkeelde võib seega pidada ka keeleõppija potentsiaalselt teadlikuks strateegiaks. Lähedase sugulaskeele õppimisel ei kasutata seda strateegiat mitte ainult teadmistes olevate lünkade täitmiseks, vaid ka sihtkeeleloome abivahendina (Kaivapalu 2005).

Teist protsessiülekande tüüpi - keeletöötluses kasutatavate kognitiivsete protsesside ülekannet (Martin 2006; Kaivapalu \& Martin 2007) - on vähe uuritud ilmselt seetõttu, et neid protsesse peetakse universaalseteks. Siiski on võimalik oletada, et eri keeltes on tõhusad ja ökonoomsed erinevad keeletöötlusprotsessid. Sellisel juhul võib ka nende protsesside suhteline tähtsus ja tööjaotus olla mõjutatud emakeelest. Eesti ja soome keele kõneleja vajab mitmekesiseid ning tõhusaid viise morfoloogiliste vormide moodustamiseks, kuid nt vietnami keele kõneleja mitte. Seega ei ole põhjust käsitada lähtekeele mõju lihtsa ja ühtse nähtusena, vaid üldise lähenemisena keele õppimisele, mille puhul õppija katsetab kõiki võimalikke keeleülekande viise (MacWhinney 1990: 78, 80; 2005). Kui keeletöötlusprotsessid on kergesti ülekantavad mistahes keelte vahel, siis mallid ja reeglite kanduvad üle pigem keeltesse, millel on sarnane struktuur, nagu siinse artikli keskmes olevas eesti ja soome keeles.

\section{Võistlusmudel}

Käesoleva uurimuse teoreetiliseks aluseks olev Elisabeth Batesi ja Brian MacWhinney 1980. aastate lõpus loodud võistlusmudel (Competition Model, MacWhinney 1987; Bates \& MacWhinney 1989) ja selle hilisemad variandid (MacWhinney 1990, 1994, 2001, 2005) on mõeldud seletama mitmekesise 
morfoloogiaga keelte õppimist. Võistlusmudelis keskendutakse keeleoskusele, mõistmisele ja keeleloomele, mitte keeleteadmistele (Martin 1995: 35-36). Võistlusmudel on funktsionalistlik ning põhineb Saussure’i keelemärgi käsitusele. Mudeli keskne mõiste on vihje (ingl cue), häälikujärjend või sõnajärjemall, mis aktiveerib keelendisse kätketud kommunikatiivse funktsiooni või tähenduse. Iga keelendit ja konstruktsiooni nähakse vihje ja funktsiooni suhtena. Keeleõppija jaoks on keeleloome seisukohalt tähtsaim vihje tugevus (cue strength), mis omakorda sõltub vihje tunnetatavusest (perceivability) ja tuntavusest (assignability). Oluline on ka vihje usaldatavus: kui vihje on õppija seisukohalt mitmetähenduslik, ei ole see usaldatav ja õppija peab valima produtseerimisprotsessi ajal mitme omavahel võistleva variandi vahel; kui vihje võimaldab vaid üht produtseeritavat varianti, on see usaldatav. Niisiis on tegemist konnektsionistliku mudeliga, viimaste aastakümnete areng on seda suundumust tugevdanud. Soome käändesüsteemis toimivad vihjetena esmajoones sõnalõpu häälikud. Idee keelendite omavahelisest võistlemisest ei ole uus (Martin 1995: 35), seda on rakendatud mitmes keeleteaduse valdkonnas. Siinses uurimuses nähakse keelendite võistlust kahetasandilisena: ühelt poolt võistlevad omavahel morfoloogiliste vormide käänamist mõjutavad tegurid, nagu lähte- ja sihtkeele sarnasus, sihtkeele käänamismalli produktiivsus ning käänatava sõna omadused; teisalt võistlevad tüve- ja sufiksivariantide kombinatsioonid (vt ka Kaivapalu 2005).

Võistlusmudeli järgi on lähtekeele mõju vaid üks sihtkeele õppimist määrav tegur (MacWhinney 1990: 75-85), sest õppimist nähakse lähtekeele süsteemi ümberstruktureerimisena. Niisugune lähenemine sarnaneb nii väljamorfoloogia (Paunonen 1983) kui ka skeemiteooria (Bybee 1988, 2001: 19-27) seisukohtadega. Sihtkeele süsteemi kujunemist mõjutab lisaks lähtekeele mõjule sihtkeele vihjete tugevus ja usaldatavus.

Õppimine algab ulatusliku ülekandega lähtekeelest, mis vähemalt algfaasis ei ole teadvustatud. Kui lähte- ja sihtkeel sarnanevad, siis on lähtekeele mõju enamasti positiivne. Sellele etapile järgneb pikk periood, kui õppija proovib kohandada oma keelesüsteemi võimalikult sihtkeele süsteemi sarnaseks. Need kaks süsteemi võivad sel perioodil osaliselt kattuda, eriti kui tegemist on lähisugulaskeeltega. Alles hilisemas õppimise faasis hakkavad lähte- ja sihtkeele süsteemid eralduma ning tekib arusaam, millal võib sihtkeele loomes toetuda lähtekeelele ja millal mitte. Lähtekeele mõju toimib niisiis erinevatel õppimisperioodidel isemoodi, mh sõltub see ka õppija isikuomadustest ja varasematest keeleõppimiskogemustest. Seetõttu ei nähtagi võistlusmudelis lähtekeele mõju ühese nähtusena, vaid pigem üldise lähenemisena sihtkeele õppimisele või strateegiana, mille järgi õppija katsetab kõiki võimalikke ülekandeviise. Lähtekeelest kanduvad sihtkeelde mitte ainult keeleelemendid, vaid ka keelesüsteemi toimimise põhimõtted ja keeleloomeprotsessid. 
Võistlusmudeli järgi rakendatakse morfoloogiliste vormide õppimisel ja produtseerimisel mehhaanilist moodustamist, reeglipõhist allomorfide ühendamist ja analoogiat. Mehhaanilisest moodustamisest võib rääkida siis, kui õppija kasutab õigesti tema jaoks tuttavate sõnade muutevorme, kuid ei oska käänata või pöörata tundmatuid sõnu, isegi mitte protsessi toetavas lause- ja morfoloogilises kontekstis. Ühendamisega on tegemist siis, kui õppija moodustab valesti ebareeglipäraseid vorme, kuid tehissõnu kasutab reeglipäraselt. Kõhklemine erinevate variantide vahel annab tunnistust analoogiaprotsessist.

Võistlusmudeli kohaselt proovib õppija kõigepealt ennast väljendada mehhaaniliselt, mälu põhjal. Kui see ebaõnnestub, proovib ta tüve-, tunnuse- ja lõpuallomorfide enam või vähem reeglipärast ühendamist. Võistlusmudelis lähtutakse oletusest, nagu ka SAID-mallis (Stem Allomorph / Inflectional Decomposition, vt Niemi \& Heikkinen et al. 1994), et mitmekesise muutemorfoloogiaga keeltes on keeleaines talletatud tüve-, tunnuse- ja lõpuallomorfidena. Kui ühendamise lõpptulemus on väär, siirdutakse moodustamisprotsessis vormi korrigeerimise faasi. Õppija võrdleb tulemust oma teadmistega, mis tal on õpitava keele kohta, või arvestab tagasisidega (nt õpetajalt või kaasvestlejalt saadud teave). Esimesel juhul on tegemist sisese, teisel juhul välise monitooringuga. Kui võrreldavad sõnavormid ei lange kokku, asendatakse ühendamise tulemusel saadud vorm analoogia abil moodustatud vormiga. MacWhinney väitel toetub õppija analoogiale vaid siis, kui mehhaaniline moodustamisviis ja ühendamine ebaõnnestuvad, ning allomorfide ühendamisele juhul, kui soovitava vormi mehhaaniline produtseerimine ei anna tulemust. Keeleõpet ja keelekasutust käsitatakse kontiinumina mehhaanilisest produtseerimisest analoogiani, kus kontiinumi igal strateegial on oma ülesanne. Eesti ja vene lähtekeelega õppijate soome käändevormide produtseerimist käsitlev uurimus (Kaivapalu 2005: 265-272) osutab siiski, et võistlusmudeli keeleloomestrateegiate järjestus peab paika venekeelsete õppijate ehk sihtkeelest kaugema lähtekeele puhul. Eestikeelsed õppijad rakendavad mehhaanilise produtseerimise ebaõnnestumisel valdava strateegiana lähtekeele, aga ka sihtkeele analoogiat. Kui ka analoogiapõhine produtseerimine ebaõnnestub, püüavad nad kasutada reegleid. Seega mõjutab õppijate lähtekeel keeleloomestrateegiate (teadvustamata) valikut ja nende kasutamisjärge.

\section{Ainestik ja meetod}

Artiklis käsitletakse keeltevahelise sarnasuse tunnetamise ja lähtekeele positiivse mõju seoseid testiolukorras ning õppetöö käigus kogutud ainestiku põhjal. See võimaldab mh analüüsida lähtekeele positiivse mõju erisusi struktureeritud ja spontaanses ainestikus. 
Testiolukorras kogutud valjusti mõtlemise protokollide ja intervjuude aluseks oli kolmekümnest käändsõnast koosnev üksiksõnatest. Testis osalejatel paluti käänata ainsuse nimetavas käändes olevaid sõnu mitmuse osastavas, sisseütlevas ja seestütlevas käändes. Testitavate käänete järjekord oli seega sama kui eesti koolide soome keele õpetuses, kus lähtutakse traditsiooniliselt eesti, mitte soome keele käänete järjekorrast. Testiülesanded olid arusaadavuse tagamiseks õppijate emakeeles. Kahesilbiliste testisõnade valiku aluseks oli soome käändsõnade sarnasus ja erinevus võrreldes eesti keelega (käänamistesti detailsemat kirjeldust vt Kaivapalu 2006: 80-86). Fonoloogilise, morfoloogilise ja semantilise sarnasuse alusel moodustus neli sõnarühma.

1) Sõnadel on lähte- ja sihtkeeles sama või väga lähedane tüvi ning testitavates käänetes vähemalt üks samamoodi käänduv paralleelvorm, nt

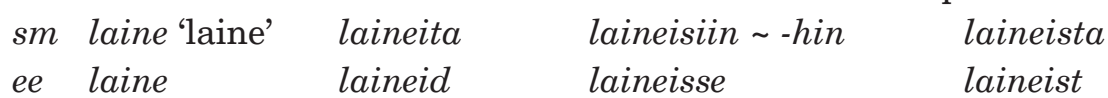

2) Lähte- ja sihtkeele sõnade tüved erinevad, kuid käänamismall on sama, nt sm patsas 'ausammas' patsaita patsaisiin $\sim-$ hin patsaista ee kitsas kitsaid kitsaisse kitsaist

3) Sõnadel on lähte- ja sihtkeeles sama (väga lähedane) tüvi, kuid sõnad käänduvad erinevalt, nt

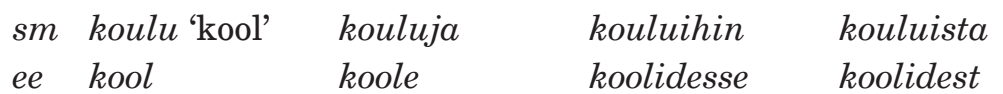

4) Sõnadel on erinev tüvi ja ka erinev käänamismall, nt

sm veistos 'skulptuur' veistoksia veistoksiin veistoksista

ee skulptuur skulptuure skulptuuridesse skulptuurides

Testis esinevate tehissõnade käänamise eesmärk oli selgitada, kuidas toimib keeleõppija nende produtseerimisel, sest need pole kindlasti mällu talletatud. Käänamistesti tehissõnad nirkas, syhmä, sulkki ja veule moodustati soomekeelsetest sõnadest kirkas 'kirgas', tyhmä 'rumal', tulkki 'tõlk' ja neule 'kudum' algustähe asendamisega.

Mitmuse osastav ja seestütlev valiti testitavateks kääneteks seetõttu, et teatud muuttüüpide (PS 41 vieras- ja 48 hame-tüüp) käänamine on vähemalt ühes paralleelvormis eesti ja soome keeles sarnane (arvestamata eesti keeles toimunud lõpukadu): ee herneid : herneist ja sm herneitä : herneistä; ee võõraid : võõraist ja sm vieraita : vieraista. Samuti on mitmuse osastav oluline kääne soome keele õpetamise seisukohalt: paljudes õpikutes alustatakse mitmuse vormide õpetamist osastavast (nt Sark 1995, 2009; Parviainen \& Sander 1998). Eesti ja soome sisseütlev seevastu erinevad nii käändelõpu kui ka astmevahel- 
duslike sõnade astme poolest, kuid mainitud käändtüüpides on käänamismall (tüve ja tunnuse kombinatsioon) käändelõppu arvestamata siiski sarnane.

Artiklis käsitletakse vaid kahte esimest sõnarühma: ühes on eesti ja soome keeles samatüvelised ning samamoodi käänduvad sõnad, teises eritüvelised, kuid samuti samamoodi käänduvad sõnad. Tähelepanu keskmes on niisiis kahe keele morfoloogiline sarnasus, mida vaadeldakse käänamismallide sarnasuse põhjal. See on sarnasuse tunnetamiseks ja lähtekeele positiivse mõju toimimiseks vajalik ühisosa (vt Martin 2006). Samas ei ole selliseid sõnu võrreldavates keeltes kuigi palju (Tuomi 1980: 133-137, 140-146, 353-356), mistõttu ei olnud testisõnade valikul kuigi avaraid võimalusi.

Testimaterjal on kogutud Tartu tollasest Forseliuse Gümnaasiumist aastatel 2001 ja 2002 ning Kärdla Keskkoolist aastal 2002. Testis osalejad olid alustanud soome keele õpinguid kolmanda ehk C-võõrkeelena 10. klassi sügisel ning läbinud testi sooritamise ajaks (12. klassi teiseks poolaastaks) sama õppekava (SKAR 1997: 30-32) alusel ja sama õpiku (Sark 1994, 1995) järgi umbes 200 tundi. Muid kontakte soome keelega õpilastel polnud, seega oli tegemist puhtakujulise võõrkeeleõppega väljaspool keelekeskkonda. Informantide vanus 17-18 aastat tähistab kognitiivse arengu mõttes noori täiskasvanuid (Jaakkola 1997: 68). Testi kirjaliku sooritamise ajal paluti üheksal osalejal kirjeldada valjusti oma mõtteid ja tegevust testisõnade käänamisel. Eesmärk oli 1) heita valgust õppijate produtseerimisprotsessile (Block 1992; Swain \& Lapkin 1995), mis tavaliselt jääb kättesaamatuks, 2) uurida, milliseid käänamisstrateegiaid kasutatakse, 3) kuidas emakeel mõjutab produtseerimisstrateegia valikut. Pärast testi sooritamist intervjueeriti osalejaid ja paluti neil oma tegevust selgitada, vajadusel ka täpsustada. Nii introspektiivne valjusti mõtlemine kui ka retrospektiivne intervjuu viidi läbi õppija emakeeles, antud juhul eesti keeles. Kuna testis 2001. aastal osalenud Tartu õpilased ei olnud sisseütlevat käänet veel õppinud, paluti neil moodustada mitmuse seesütleva vormid.

Eestikeelsete soome keele õppijate spontaanset keelekasutust analüüsiti Helsingi algkooli immigrantide ettevalmistava õppe käigus kogutud videomaterjali põhjal. Materjal lindistati soome keele kui teise keele tundides kaks korda nädalas (teisipäeviti ja neljapäeviti) ühe õppeaasta jooksul septembrist maini. Õppetundide materjal litereeriti ELAN-programmiga. ${ }^{1}$ Kone fondi rahastatud projekti The Long Second: LONGitudinal classroom data about children's development in Finnish as a SECOND language ("Long Second: Pikiuuring soome keele oskuse arengust algkooli immigrantide ettevalmistava õppe rühmas")2. 10-12-aastaste õpilaste seas oli lisaks enim esindatud eesti- ja venekeelsetele õpilastele kurdi-, läti-, makedoonia- ja portugalikeelseid lapsi. Omavaheline suhtlus toimus vajadusel ka inglise keeles.

Mõlema ainestiku analüüs on kvalitatiivne, käänamistesti kvantitatiivsed tulemused on esitatud varasemates uurimustes (vt Kaivapalu 2005, 2006: 
80-93; Kaivapalu \& Martin 2007). Kummagi sihtrühma keeleloomeprotsessi analüüsis ei ole arvestatud vokaalharmoonia- ja õigekirjavigu, sest uurimus keskendub eelkõige sellele, kuidas õppijad morfoloogiliste vormide produtseerimisprotsessis kombineerivad tüve-, tunnuse- ja lõpuallomorfe, eriti olukorras, kui on võimalus valida mitme tunnuse- ja lõpuvariandi vahel. Õppijate sõnastused on esitatud muutmata kujul. Testiainestikus tähistab üks kaldkriips lühemat ja kaks kaldkriipsu pikemat pausi vormi produtseerimisel.

\section{Keeltevahelise sarnasuse tunnetamisest positiivse keeltevahelise mõjuni või siiski mitte}

Selles peatükis on vaatluse all eesti ja soome keeles samatähenduslike, samatüveliste ja samamoodi käänduvate ning eritüveliste, kuid ikkagi samamoodi käänduvate sõnade sarnasuse tunnetamisprotsess. Alapeatükis 5.1 käsitletakse juhtumeid, milles sarnasuse tunnetamine on viinud elemendi- ja/või süsteemiülekandeni eesti keelest soome keelde ning analüüsitakse selle põhjusi. Alapeatükis 5.2 keskendutakse lähtekeele positiivse mõju realiseerumist takistavatele teguritele.

\subsection{Elemendi- ja süsteemiülekanne}

\subsubsection{Elemendiülekanne}

Samatähenduslike ja sama või lähedase tüvega ning samamoodi käänduvate sõnade sarnasuse tunnetamisel on oluline roll sõna tähendusel: kui õppija taipab vaatamata eesti ja soome keele väikestele süstemaatilistele erinevustele (vokaalharmoonia, lõpukadu jne), et tegemist on sama tähendusega sõnaga kui eesti keeles, ja julgeb loota sarnasusele oma emakeelega, siis on morfoloogiliseks keeleülekandeks vajalik keeltevaheline vastavus identifitseeritud. Sellisel juhul kandub lähtekeelest sihtkeelde üle enamasti kas käändevorm või käänamismall tervikuna. Näiteks:

herne herneita see on vist hernes herneista

toinen toisia see võiks nüüd olla selle järgi, et eesti keeles on teine ja teisi tuote tuot / tei / ta tuot / teista toode

Lähtekeele käändevormid siirduvad sihtkeelde ka siis, kui tähendust ei teata või seda ei mainita. Näiteks:

talvirengas talvirenkaita talvirenkaista tähendust ma nagu tõesti ei oska panna 
talvirengas on siis talviren/gai/ta talvirengai/ssa talvirengaista vilkas vilk- vilkkaita vilkkaista

Kui eesti ja soome keeles on sama käänamismall, siis kandub see sihtkeelde üle ka siis, kui sõnade tüved ja tähendus erinevad. Näiteks:

kohde kohteita kohteista Mis see võiks tähendada? koht? patsas patsaita patsaista

Osa emakeele morfoloogiliste vormide positiivsest ülekandest paistab õppijate kommentaaride põhjal olevat teadvustamata tegevus: emakeelega sarnase vormi valikut põhjendatakse sellega, et sihtkeele väga produktiivset muuteformatiivi -jA (Niemi \& Heikkinen et al. 2001: 196) sisaldav vorm ei tundu olevat loogiline või et sõna mäletatakse. Näiteks:

herne herneita, sest et herneja ei tundu loogiline

herne hern / / ei/ta ma mäletan seda sõna herneista hernes

Viimasest õppija kommentaarist ei selgu, kas sõna mäletatakse õpitavast keelest, kuid ei ole võimatu, et sõna "mäletatakse" emakeele põhjal, kuigi antud materjal ei võimalda seda kindlalt väita. Üldjuhul on õppijad siiski potentsiaalselt teadlikud eesti ja soome käändevormide oletatavast sarnasusest, sest intervjueerija küsimuse peale osatakse nimetada testisõnu, mille vormimoodustuses emakeelele toetutakse. Näiteks:

- vieras vie / rai / ta. See on vist lihtsalt tuttav sõna, mälu järgi vist [moodustasin vormi] vieraisiin vieraista võõras vist

- Kas sa mõne sõna puhul mõtled seda ka, et näe eesti keeles on niimoodi?

- Jaa.

- No näiteks millise sõna puhul sa niimoodi mõtlesid?

- kool, raamat, kaubamaja

- Kas siin on mõni niisugune sõna, mille puhul sa mõtlesid, et eesti keeles on samamoodi?

- Vist mõni on.

- Näiteks kus sa tegid eesti keele järgi?

- herne, siis kangas võib-olla. Peaaegu kõik tegin nagu eesti keeles, välja arvatud need, mida ma kindlalt teadsin.

- Et on soomekeelne sõna ja eesti keeles on teistmoodi jah?

- Noh kui teadsin, kuidas soome keeles on.

Klassiruumis peetud vestlustes esineb rohkelt elemendiülekande juhtumeid. Kui lähte- ja sihtkeele sõnad on sarnased, nagu järgnevas näites eesti ja soome kõnekeeles, realiseerub sarnasuse tunnetamine sihtkeelepärase keelekasutusena. Näiteks: 
Sirpa: mitä syö kesällä porot.

Eetu: lehti.

Sellest näitest ei selgu, kas lehti on eesti- või soomekeelne sõnavorm, kuid kuna õppijate eesmärk on rääkida soome keele tunnis soome keelt, siis võib oletada, et Eetu vähemalt enda arvates kasutab soome keelt.

Järgnevas vestluses esineb üsna mitu võimalust keeltevahelise vastavuse identifitseerimiseks. Näiteks:

Eimar: ta, (.) ta hea- (.) eläb metsassa.

Ebba: kettu sööb inimest.

Eetu: kettu syö ihmise.

Eimari mõtteavaldus algab eesti keeles, kuid sellele järgnevast vastavuste otsimisest annab tunnistust nn segavormide kasutamine, vrd eesti keeles elab metsas ja soome keeles elää metsässä. Eimar on juba tunnetanud tähenduste sarnasust, kuid oma mõtte morfoloogilisel keelendamisel kasutab ta mõlema keele elemente. Antud näite põhjal on Eimari keeleoskus arengufaasis, mil õppija proovib kohandada oma keelesüsteemi sihtkeele süsteemi sarnaseks, kuid lähte- ja sihtkeele süsteemid kattuvad veel osaliselt. Eetu seevastu on lisaks tähenduse sarnasusele tunnetanud ka morfoloogiliste vormide sarnasust, verbide puhul konkreetsete vormide ja käändevormide puhul käändeparadigmade sarnasust (eesti ainsuse osastav ja soome ainsuse omastav).

Kahe keele süsteemide kattumist peegeldab ka järgmine näide Eimari keelekasutusest:

Eimar: voibko ää voibko valita.

Eimar: neid ei saa võttagi. (.) ottagi. neid ei saa ottagi.

Suuresti lähtekeelele tuginevas oletusfaasis, kus õppija püstitab keeltevahelise oletatava sarnasuse põhjal hüpoteese sihtkeele kasutuse kohta, on oluline õpetaja tagasiside, eriti juhtudel, kui keelendite sarnasus ei ole täielik. Näiteks:

Suvi-tchr: Radimir tiesi tämän Aamu-kirjasta hienoa. (.) mahtavaa. (.) no sitten äm pee. (1.0) a mikäs tämä on.

Eetu: $\quad$ kammi.

Eimar: $\quad$ kammi.

Suvi-tchr: mikä?

Eimar: kammi.

Suvi-tchr: $\quad$ se on viroks se mut suomeks se on kam-,

Eetu: kamma.

Eimar: kamma.

Suvi-tchr: kamPA,

Eetu: $\quad$ näh. (.) ma ütlen alati valesti. 
Õppijad on niisiis tunnetanud lisaks tähenduse sarnasusele süstemaatilist vastavust eesti tüvevokaalita lõpukaolise ainsuse nimetava ja soome vokaallõpulise nimetava vahel, kuid sarnasuse tunnetamine soome laadivaheldusliku ja eesti vältevaheldusliku käänamise vahel ei ole veel selles õppimise faasis nii iseenesest mõistetav.

\subsubsection{Süsteemiülekanne}

Nii mõneski valjusti mõtlemise näites on soome keele vokaaltüvelise $i$-mitmuse vormi moodustamise malliks hoopis eesti keele konsonanttüvelise de-mitmuse vorm. Näiteks:

laine laineja laineista ei laineista laineista. laineista, selle sõna puhul ma oletan, et see tähendab lainet ja siis ja siis laintest oleks eesti keele seestütlev. Ma teen siis seestütleva eesti keele järgi: laineista.

kangas see on eesti keelega sarnane kangaita kangastest kangai- kangia ei kangaista

Antud juhul on tegemist süsteemiülekandega: õppijad toetuvad emakeele morfoloogiasüsteemi toimimise põhimõttele, mille järgi mitmuse vormide käänamisel liidetakse tüvevariandile mitmuse tunnus ja käändelõpp. Lähtekeelest sihtkeelde kandub seega morfoloogilise vormi moodustusmehhanism, aglutinatsioon, ning konkreetne mitmuse morfeemivariant on seejuures teisejärguline. Süsteemiülekanne on niisiis paradigmaatiline: vastavuste leidmisel ei toetuta mitte ainult võrreldavatele vormidele, vaid kogu vormistikule, sh muutevormidele, mida testiülesandes ei küsita. Näiteks soome keele mitmuse osastava käände vormi moodustamisel toetub õppija nii eesti keele ainsuse kui ka mitmuse osastavale:

herne hernest herneid herneita hernei/ssa hernei/sta

Morfoloogiliste paradigmade olulisust keeltevaheliste vastavuste loomisel näitab veenvalt ka klassiruumi spontaanne keelekasutus, kui õpilane otsib sarnasust eesti sõna põld ja soome sõna pelto vahel ning võrdleb omavahel eesti ainsuse osastavat ja soome ainsuse nimetavat. Näiteks:

Eetu: peltu (2.0) ja põldu. (.) põldo. (.) palto pelto pulto.

Ülekandemehhanismid on seega konkreetse keelendi ülekandest märgatavalt mitmekesisemad, hõlmates ka teisi paradigma muutevorme.

Keeltevahelise sarnasuse tunnetamine lähte- ja sihtkeele vormides viib keeleloomes oletuseni, et ka teised sama paradigma vormid sarnanevad, nt on 
sarnased soome ja eesti mitmuse nimetav hampaat ja hambad ning mitmuse osastava käände vormid hambaid ja hampait(a):

$\begin{array}{ll}\text { Suvi-tchr: } & \text { Miks pitää pestä hampaat, minkä takia? } \\ \text { Eetu: } & \text { s- sitten (.) kun ei ole kuukausi a- hampaid pesnud } \\ & \text { sitten ää “klõnk klõnk klõnk klõnk klõnk klõnk klõnk } \\ & \text { ruhh.” (.) eheh heh } \\ \text { Suvi-tchr: } & \text { Miks tuleb hambad (ära) pesta, mille pärast? } \\ \text { Eetu: } & \text { s- siis (.) kui ei ole kuu (aega) a- hambaid pesnud siis } \\ & \ddot{a ̈ a ̈ ~ " k l o ̃ n k ~ k l o ̃ n k ~ k l o ̃ n k ~ k l o ̃ n k ~ k l o ̃ n k ~ k l o ̃ n k ~ k l o ̃ n k ~ r u h h . " ~} \\ & \text { (.) eheh heh' }\end{array}$

Sellest, et mitmuse vormi moodustamine nõuab tavapärasest enam aega, annab tunnistust kõnevoo hetkeline peatumine enne mitmuse osastava produtseerimist. Igasugune paus kõneleb siin protsessi keerukusest. Arvestama peab ka seda, et antud näites on tegemist soome kõnekeelega, milles eesti keelega sarnaselt on lõpuvokaalid kadunud ning lähedus eesti keelega seetõttu suurem kui soome üldkeelel.

Vaadeldud näited osutavad, et sarnasuse tunnetamine lähte- ja sihtkeele muutemorfoloogia elementide vahel on mitmeastmeline ega tarvitse alati hõlmata kõiki antud vormi moodustamiseks vajalikke elemente. Sellest annavad tunnistust vormid, mille tüvi võib olla sihtkeelepärane ja morfoloogilised formatiivid lähtekeelsed või vastupidi. Morfoloogiasüsteemide sarnasuse tunnetamine seevastu paistab analüüsi põhjal osalevat keeleloomeprotsessis kõikehõlmavalt. Lähedastes sugulaskeeltes ei järgne ilmselt süsteemi õppimine elementide õppimisele. Keeltevahelise sarnasuse tõttu oskab õppija emakeele põhjal juba suurt osa sihtkeele süsteemist ning teab, kuidas see üldjoontes toimib. Õppimise käigus täpsustuvad produtseeritavad vormid elementide sarnasuse tunnetamise kaudu, muutudes üha enam sihtkeelepäraseks.

\subsection{Lähtekeele analoogia ja sihtkeele reeglid võistlemas}

Eesti koolides on soome morfoloogia õpetamine olnud traditsiooniliselt reeglipõhine (Palmeos 1981: 158-159; Alvre 1967: 74-75). Muutemorfoloogia õpetamine reeglite abil on üsna järjekindlalt kasutusel pea kõikides soome keele õpikutes, isegi kui reegleid ei eksplitseerita. Ka õpik, mille järgi käesoleva uurimuse sihtrühm soome keelt õppis, lähtub soome muutemorfoloogia käsitlus reeglitest (Sark 1995: 35-39). Kui õppijad on harjunud teadmisega, et sõnal on mitmeid tüve-, tunnuse- ja lõpuallomorfe, siis saab ta neid hakata ühendama (Sark 1994: 23). Noomeni mitmusevormide käänamist õpetades järgitakse just seda põhimõtet (Sark 1995: 35-38): tüvemoodustusreeglid eelnevad tüve-, tunnuse- ja 
lõpuallomorfide ühendamisele. Analoogiat hakatakse rakendama alles siis, kui õppijad on teadlikud erinevatest tüve- ja sufiksiallomorfide kombinatsioonidest, mille vahel on võimalik valida (Sark 1995: 41-43). Seega on viidatud õpiku lähenemine morfoloogiaõpetusele võistlusmudeli kombel astmeline, kontiinumilaadne. Õppijate soome keele vormimoodustus peaks õpetuse tulemusena tuginema valdavalt reeglitele. Samas näitavad aga uurimistulemused (Kaivapalu 2005; Kaivapalu \& Martin 2007), et eestikeelsed soome keele õppijad toetuvad esmajoones lähte- ja sihtkeele analoogiale, kusjuures esimene neist tugineb paradigmade sarnasusele, teine aga üksiksõnade sarnasusele. Ei ole siis üllatav, et õpetamise tulemusena omandatud reeglipõhine vormimoodustus hakkab käänamisprotsessis võistlema emakeele analoogiaga ning takistab emakeele käänamismalli kasutust sealgi, kus see viiks sihtkeeles aktsepteeritava keelekasutuseni. Näiteks:

kangas, eestikeelne sõna kango- kangoia kanga- kan/goi/sse kangas kangaista kangoista

kangas on kangas vist kangas on see kankaita kankeita

vilkas vilkais- vil/gas vilkai-vilkaja eesti keeles on ka sama sõna vil/ kai/ta vilkai/ssa vilk/kai/sta

tuode tuot- tuoteja toode ei ole toode või? Eesti keele mitmuse osastav tooteid tuotteja tuotteissa tuotteista

Eriti selge reeglite rakendamise märk on tüvevokaali muutuse üldistamine nendesse sõnavormidesse, kus seda tegelikult ei esine. Nii laieneb tänapäeva soome keele produktiivne vaheldus $a>o$ (Niemi \& Heikkinen et al. 2001: 191), mis normikohaselt on mitmuse tüvevokaaliks vaid $a$-tüvelistes sõnades, ka teistesse muuttüüpidesse kuuluvatele sõnadele, olgugi et õppija on tunnetanud eesti ja soome sõnavormide sarnasust. Samuti üldistatakse soome $i$-tüveliste sõnade mitmuse tüvevokaal $a$-tüvelistele sõnadele ning produktiivne $j A$-lõpuline mitmuse osastav normikohaselt itA-lõpulise mitmuse osastavaga käändtüüpidele, kus emakeele käänamismall viiks sihtkeelepärase keelekasutuseni. Kümnendas klassis soome keele õpinguid alustanud õpilaste keeleoskus on gümnaasiumi lõpus just sellises arengufaasis, et muutevormide produtseerimisel kõheldakse mitme võimaluse vahel. Omavahel võistlevad ühelt poolt emakeelega sarnased sihtkeele normikohased vormid ja teisalt sihtkeele normivastased vormid. Näiteks:

- laine laineita või laineja

- Miks sa kõhklema hakkasid?

- No siin laine on selles mõttes nagu merelaine. Ei tea ka. See tuli nii 
kõhutunde järgi.

- Sisseütlev on laineja, siis lainiin. Sihuke võib olla, et -iin on lõpus?

- Põhimõtteliselt jah.

- Aga siin ei tule, jah? laineisiin siis. Seestütlev on siis ... kui on laineja, siis laineista. Tähendus ongi vist laine.

- herne herneita. Ma vist teen herneiin ja seestütlev on her/neis/ta. Tahaks tähenduseks nagu hernes panna, aga vist ikka ei ole. Ma ei tea, ma panen ikka hernes.

- tuote Ma panen tähenduse ära kohe: toode tuotteet tuotteja ei tuotteita jah tuotteihin tuot/tei/sta

- kangas kang- $a+i$, ma ei tea, kuidas see ... kangi- kangia. Ma arvan, et see on vale.

- Arvad, et on vale? Miks sa arvad, et vale on?

- Ma ei tea, tundub nagu, et see a nagu kaob ära, selles ma lihtsalt ei ole kindel. Ei tea ka, teine variant on see, et jääb alles. kangista äkki on kangaista. Kui sellest nüüd tähendus muutuks ... kangas

Õppijad seletavad kõhklemist kartusega, et produtseeritav vorm on liiga sarnane emakeelega. Testi sooritamise ajaks on neil pärast peaaegu kolme õpinguaastat nii palju kogemusi, et eesti ja soome keele tegelikku sarnasust ei saa alati usaldada. Näiteks:

- Miks just veulia? Kas sa teed mõne sõna järgi või? Või võtad eesti keele appi?

- Eesti keelt ma ei võta peaaegu kunagi appi, ma ei tea, ei oska ...

- Kas sa mõnikord mõtled ka niimoodi, et ma teen sellepärast selle vormi niimoodi, et eesti keeles on ka nii?

- Jaa, loomulikult. Jah, aga samas ma muudan meelega midagi, et ta ei oleks täpselt nagu eesti keeles.

- kangas on kangas vist kangas on see kankaita kankeita

- Miks sa alguses kangaita vastasid?

- See on nagunii vale.

- Kui sa mõtled, et sõna on nagu eesti keeles, kas sa siis moodustad eesti keele järgi ka või?

- Ei, eesti keele järgi ma ei moodusta.

- Miks sa ei moodusta, oskad sa öelda?

- Ma ei ole hakand nagu moodustama, proovin ikka mõelda, kuidas soome keeles on. Need on ikka üpris erinevad ka, eesti keeles moodustamine ja 
soome keeles moodustamine. Mulle on jäänud selline mulje, siis ei hakka.

- Kardad, et ajab segadusse?

- Nojah.

- Ei julge nagu eesti keelt appi võtta?

$-\mathrm{Ei}$.

- herne on ... hernes ta ei ole ju?

- Miks sa arvad, et ei ole?

- Sest et petab.

- Nii sarnane ei tohi olla, jah?

- Ei tohi jah.

- talvirengas ren- rengas rengas kangas rengas kangas kangaita. Ma ei saa midagi teha, kui see eesti keelega ei ühti.

- Mõne koha peal jälle ühtivad.

- Mõne koha peal ühtivad, mõne koha peal ei ühti.

- Ütle mulle niisugust asja, kas sul on mõned niisugused sõnad siin selles loetelus, mis tunduvad väga eesti keele moodi olevat?

- Jaa. koulu, vieras, tuote, herkku, herne, kirje, opas, kangas, sulkki, laine, kirkko, lelu, toinen

- Kas sa mõnikord mõtled ka niimoodi, et ma teen sellepärast selle vormi niimoodi, et eesti keeles on ka nii?

- Jaa, loomulikult.

- Ikka mõtled? Oskad sa öelda ka, milliste sõnade puhul sa niimoodi mõtlesid?

- kool koulu, lelu, toinen ja siis laine ja mis siin on tuote ja vieras. Kõigi nende puhul tegelikult, mis eesti keele moodi tunduvad, nendele võib kõigile kastid ümber tõmmata.

- Ja mõtled ikka, et teed nii nagu eesti keeles?

- Jah, aga samas ma muudan meelega midagi, et ta ei oleks täpselt nagu eesti keeles või nagu siin on, et eespool on see olemas see vorm juba mingisuguse sõna puhul, siis nagu muudan, püüan sarnaseks teha veidikene, aga samas eesti keelega on nagu ka seotud.

Seega on metalingvistiline teadlikkus nii muutevormide produtseerimisel kui ka sihtkeele õppes üldisemalt võtmeküsimus: usaldamaks lähte- ja sihtkeele tegeliku sarnasuse tunnetamist, vajab õppija kindlust, et lähtekeele malli kasutamine viib tõepoolest ka sihtkeelepärase keelekasutuseni. Teisisõnu, on vaja teadmist, millal lähte- ja sihtkeele sõnavormide sarnasusega kaasneb ka muutemalli sarnasus ja millal mitte. 


\section{Kokkuvõte}

Uue keele õppimisel püüab õppija kas teadlikult või ise seda teadvustamata tugineda keeltevahelisele sarnasusele nii palju kui võimalik. Suutlikkus keeltevahelist tegelikku sarnasust tunnetada võib seejuures olla vägagi varieeruv, sõltudes õppija varasemast keeletaustast ja keeleõppekogemusest, üldteadmistest, metalingvistilisest teadlikkusest ja paljudest muudest teguritest. Kui keeleõppijad oskavad näha sarnasusseost lähte- ja sihtkeele elementide vahel ja kasutavad sarnasuse tunnetamise tulemusena sihtkeelega sarnast lähtekeele elementi ka sihtkeeles, siis realiseerub tunnetatud sarnasus lähtekeele positiivse mõjuna. Siiski ei kasuta õppijad lähtekeele malli alati seal, kus see võiks viia sihtkeeles normikohase keelekasutuseni, kuigi nad on tunnetanud lähte- ja sihtkeele elementide vahelist sarnasust. Siinses artiklis analüüsitud materjali põhjal on soome keelt võõrkeelena õppivatel eesti gümnaasiumiõpilastel selleks kaks peamist põhjust.

Esiteks on gümnaasiumis soome keele õpinguid kolmanda võorkeelena alustanud viimaseks gümnaasiumiaastaks algõpetuse juba läbinud ja omavad seega mõningat kogemust eesti ja soome keele sarnasusest ja erinevusest. Oma kogemuse põhjal ja õpetamise tulemusena teavad nad, et eesti ja soome keeles võib pealtnäha sarnaseid sõnu käänata/pöörata ühtmoodi või erinevalt. Seetõttu hakkab õppija kõhklema eri tüve- ja formatiiviallomorfide kombinatsioonide vahel, mis annab tunnistust analoogia rakendamisest. Õpingute algusest on õpetajad rõhutanud, et soome keel ei ole ikka päris sama kui eesti keel ja seda tuleb hoolega õppida. See võimendab kartust kasutada lähtekeele malli ka seal, kus see viiks sihtkeelepärase keelekasutuseni. Seetõttu muudetakse lähtekeele analoogiale tuginedes sihtkeelses produktsioonis midagi teadlikult teistsuguseks, et vältida liigset sarnasust õppija emakeelega.

Teiseks soodustab analoogiamallide ja reeglipõhiselt moodustatud vormide omavahelist võistlust soome muutemorfoloogia traditsiooniline reeglitele tuginev õpetamine, mis hakkab takistama eestikeelsetele õppijatele üldiselt omast analoogiale tuginevat vormimoodustust. Seega on üsna ootuspärane, et enamasti võistlevad võõrkeeleõppijate keeleloomeprotsessis omavahel lähteja sihtkeeles sarnane sihtkeelepärane vorm ning sihtkeele produktiivset tüve ja/või muuteformatiivi sisaldav reeglipõhiselt moodustatud, kuid sihtkeeles normivastane vorm. Soome keelt keelekeskkonnas teise keelena omandavate algkooliõpilaste keeleloomes selliseid tõrkeid ning analoogia- ja reeglipõhise produtseerimise võistlusest tulenevaid takistusi ei esine. Nemad lähtuvad vormimoodustuses üsna järjekindlalt emakeelest, sest on ära tunnetanud, et kahe keele morfoloogiasüsteemid toimivad üldjoontes samamoodi. Vähehaaval täienevad nii soome keelt võõrkeelena kui ka teise keelena õppijate keelekasutuses lähtekeele elemendid sihtkeelsete elementidega ja lähenevad üha enam 
sihtkeelepärasele keelekasutusele. Seega on põhjust arvata, et lähedase sugulaskeele morfoloogia õppimisel eelneb süsteemi õppimine elementide õppimisele. Kui õppija on tunnetanud kahe keele morfoloogiasüsteemide sarnasust, teab ta oma emakeele põhjal üldjoontes, kuidas sihtkeele süsteem toimib. Sihtkeele elementide õppimise ja nende sarnasuse või erinevuse tunnetamisel täpsustuvad sihtkeele morfoloogilised vormid ja muutuvad üha enam sihtkeelepäraseks.

\section{Kommentaarid}

1 https://tla.mpi.nl/tools/tla-tools/elan/ - 12. oktoober 2017.

${ }^{2}$ http://blogs.helsinki.fi/kielen-ja-kirjallisuuden-didaktiikan-tutkimus/in-english/longsecond/ - 12. oktoober 2017.

\section{Kirjandus}

Abrahamsson, Niclas 2015. Nästan infödd behärskning i ett andraspråk - en effekt av inlärningsålder eller av tvåspråkighet? NORDAND12: Andrespråklæring og andrespråksundervisning $i$ et livsløpsperspektiv, 11.-13.06.2015, Hamar. Høgskolen i Hedmark og Multiling, Universitetet i Oslos senter.

Alvre, Paul 1967. Soome keele õpik iseõppijaile. Tallinn: Valgus.

Andersen, Roger 1983. Transfer to somewhere. Gass, Susan \& Selinker, Larry (toim). Language Transfer in Language Learning. Rowley, MA: Newbury House, lk 77-95.

Bates, Elisabeth \& MacWhinney, Brian 1987. The competition, variation and language learning. MacWhinney, Brian (toim). Mechanisms of Language Acquisition. Hillsdale, NJ: Lawrence Erlbaum Associates, lk 157-193.

Bates, Elisabeth \& MacWhinney, Brian 1989. Functionalism and the competition model. MacWhinney, Brian \& Bates, Elisabeth (toim). The Crosslinguistic Study of Sentence Processing. Cambridge: Cambridge University Press, lk 3-73.

Block, Ellen L. 1992. See how they read: Comprehension monitoring of L1 and L2 readers. TESOL Quarterly 26 (2), lk 319-343.

Bybee, Joan 1988. Morphology as lexical organisation. Hammond, T. Michael \& Noonan, P. Michael (toim). Theoretical Morphology. San Diego: Academic Press, lk 119-141.

Bybee, Joan 2001. Phonology and Language Use. Cambridge Studies in Linguistics. New York: Cambridge University Press (doi: 10.1017/CBO9780511612886).

De Angelis, Gessica \& Selinker, Larry 2001. Interlanguage transfer and competing linguistic systems in the multilingual mind. Cenoz, Jasone \& Hufeisen, Britta \& Jessner, Ulrica (toim). Crosslinguistic Influence in Third Language Acquisition: Psycholinguistic Perspectives. Clevedon, UK: Multilingual Matters, lk 42-58.

Duškova, Libuse 1984. Similarity: An aid or hindrance in foreign language learning? Folia Linguistica 18, lk 103-115.

Jaakkola, Hanna 1997. Kielitieto kielitaitoon pyrittäessä. Vieraiden kielten opettajien käsityksiä kieliopin oppimisesta ja opettamisesta. Jyväskylä Studies in Education, Psychology and Social Research 128. Jyväskylä: Jyväskylän yliopisto. 
Jarvis, Scott 2000. Methodological rigor in the study of transfer: Identifying L1 influence in the interlanguage lexicon. Language Learning 50 (2), lk 245-309 (doi: 10.1111/00238333.00118).

Jarvis, Scott 2010. Comparison-based and detection-based approaches to transfer research. Roberts, Leah \& Howard, Martin \& Ó Laoire, Muiris \& Singleton, David (toim). EUROSLA Yearbook 10. Amsterdam: Benjamins, lk 169-192 (doi: 10.1075/eurosla.10.10jar). Jarvis, Scott \& Odlin, Terence 2000. Morphological type, spatial reference, and language transfer. Studies in Second Language Acquisition 22 (4), lk 535-556.

Jarvis, Scott \& Pavlenko, Aneta 2008. Crosslinguistic Influence in Language and Cognition. New York \& London: Routledge.

Kaivapalu, Annekatrin 2005. Lähdekieli kielenoppimisen apuna. Jyväskylä Studies in Humanities 44. Jyväskylä: Jyväskylän yliopisto.

Kaivapalu, Annekatrin 2006. Kontrastiivlingvistika ja võõrkeele õppimine. Metslang, Helle \& Soidro, Siiri (toim). Lähivertailuja 16. Soome-eesti kontrastiivseminar Männikul 8.-9.05.2004. Tallinna Ülikooli eesti filoloogia osakonna toimetised 6. Tallinn: TLÜ Kirjastus, lk 71-99.

Kaivapalu, Annekatrin 2015. Eesti ja soome keele vastastikune mõistmine üksiksõna- ja tekstitasandil: lingvistilised tegurid, mõistmisprotsess ja sümmeetria. Eesti Rakenduslingvistika Ühingu aastaraamat 11, lk 55-74 (doi: 10.5128/ERYa11.04).

Kaivapalu, Annekatrin \& Martin, Maisa 2007. Morphology in transition: The plural inflection of Finnish nouns by Estonian and Russian learners. Acta Linguistica Hungarica 54 (2), lk 129-156.

Kaivapalu, Annekatrin \& Martin, Maisa 2015. Kuidas mõjutab emakeel keeltevahelise sarnasuse tunnetamist. Emakeele Seltsi aastaraamat 60 (2014), lk 74-100 (doi: 10.3176/ esa60.04).

Kellerman, Eric 1979. Transfer and non-transfer: Where we are now. Studies in Second Language Acquisition 2 (1), lk 37-57 (doi: 10.1017/S0272263100000942).

MacWhinney, Brian 1987. The Competition Model. MacWhinney, Brian (toim). Mechanisms of Language Acquisition. The 20th Annual Carnegie Symposium on Cognition. New Jersey: Erlbaum, lk 249-308.

MacWhinney, Brian 1990. Psycholinguistics and foreign language acquisition. Tommola, Jorma (toim). Vieraan kielen ymmärtäminen ja tuottaminen. AFinLA:n vuosikirja 1990. Suomen soveltavan kielitieteen yhdistyksen julkaisuja 48, lk 71-87.

MacWhinney, Brian 1994. The dinosaurs and the ring. Corrigan, Roberta \& Iverson, Gregory \& Lima, Susan (toim). The Reality of Linguistic Rules. Amsterdam: Benjamins, lk 283-320.

MacWhinney, Brian 2001. Emergentist approaches to language. Bybee, Joan \& Hopper, Paul (toim). Frequency and the Emergence of Linguistic Structure. Amsterdam \& Philadelphia: Benjamins, lk 449-470.

MacWhinney, Brian 2005. A unified model of language acquisition. Kroll, Judith F. \& de Groot, Annette M. B. Handbook of Bilingualism: Psycholinguistic Approaches. Oxford: Oxford University Press, lk 49-100. 
Martin, Maisa 1995. The Map and the Rope. Finnish Nominal Inflection as a Learning Target. Studia Philologica Jyväskyläensia 38. Jyväskylä: University of Jyväskylä.

Martin, Maisa 2006. Suomi ja viro oppijan mielessä. Näkökulmia taivutusmuotojen prosessointiin. Lähivertailuja 17. Jyväskylä Studies in Humanities 53. Jyväskylä: University of Jyväskylä, lk 43-60.

Möhle, Dorothea \& Raupach, Manfred 1989. Language Transfer of Procedural Knowledge. Dechert, Hans W. \& Raupach, Manfred (toim). Transfer in Language Production. Norwood, NJ: Ablex Publishing Corporation, lk 195-216.

Niemi, Jussi, Laine, Matti \& Tuominen, Juhani 1994. Cognitive morphology in Finnish: Foundations of a new model. Language and Cognitive Processes 9, lk 423-446 (doi: 10.1080/01690969408402126).

Niemi, Jussi \& Heikkinen, Janne \& Järvikivi, Juhani 2001. Miksei kania vaikka munoja? Sulkala, Helena \& Nissilä, Leena (toim). XXVII kielitieteen päivät Oulussa 19.-20.5.2000. Acta Universitatis Ouluensis B Humaniora 41. Oulu: Oulun yliopisto, lk 191-197.

Odlin, Terence 1989. Language Transfer. Cross-Linguistic Influence in Language Learning. Cambridge, USA: Cambridge University Press (doi: 10.1017/CBO9781139524537).

Palmeos, Paula 1981. Soome keele õpik. Tallinn: Valgus.

Parviainen, Aira \& Sander, Klarika 1998. Löytöretki Suomeen. Helsinki: Finn Lectura.

Paunonen, Heikki 1983. Allomorfien dynamiikkaa. Hakulinen, Auli \& Leino, Pentti (toim). Nykysuomen rakenne ja kehitys. Näkökulmia kielen rakenteisiin 1. Tietolipas 93. Helsinki: Suomalaisen Kirjallisuuden Seura, lk 57-85.

Ringbom, Håkan 1987. The Role of the First Language in Foreign Language Learning. Clevedon: Multilingual Matters LTD.

Ringbom, Håkan 2007. Cross-Linguistic Similarity in Foreign Language Learning. Clevedon: Multilingual Matters LTD.

Ringbom, Håkan \& Jarvis, Scott 2009. The importance of cross-linguistic similarity in foreign language learning. Long, Michel H. \& Doughty, Catherine J. (toim). Handbook of Language Teaching. Oxford: Blackwell, lk 106-118.

Sark, Kaare 1994. Yy kaa koo. Suomea kouluille 1. Tallinn: ESKO Koolitus.

Sark, Kaare 1995. Yy kaa koo. Suomea kouluille 2. Tallinn: ESKO Koolitus.

Sark, Kaare 2009. Hyvä-parempi-paras. Soome keele õppekomplekt algajaile. Tallinn: Iduleht.

Schepens, Job \& van der Slik, Frans \& van Hout, Roeland 2013. The effect of linguistic distance across Indo-European mother tongues on learning Dutch as a second language. Borin, Lars \& Saxena, Anju (toim). Approaches to Measuring Linguistic Differences. Berlin: Mouton de Gruyter, lk 201-233.

Selinker, Larry \& Lakshmanan, Usha 1992. Language transfer and fossilization: The Multiple Effects Principle. Gass, Susan \& Selinker, Larry (toim). Language Transfer in Language Learning. Amsterdam: Benjamins, lk 197-216 (doi: 10.1075/lald.5.13sel).

SKAR 1997 = Soome keele aineraamat 1997. Soome keel. C-keele ainekava . Tallinn: Eesti Vabariigi Haridusministeerium, lk 30-32. 
Swain, Merrill \& Lapkin, Sharon 1995. Problems in output and the cognitive processes they generate: A step toward second language learning. Applied Linguistics 16 (3), lk 371-391 (doi: 10.1093/applin/16.3.371).

Tuomi, Tuomo 1980. Suomen kielen käänteissanakirja. Reverse Dictionary of Modern Standard Finnish. Suomalaisen Kirjallisuuden Seuran toimituksia 274. Helsinki: Suomalaisen Kirjallisuuden Seura.

\title{
Summary
}

\section{The journey of language learners from perceiving cross-linguistic similarity to target-like language use}

\author{
Annekatrin Kaivapalu \\ Professor of Finnish, University of Turku \\ editor-in-chief of the journal Lähivorrdlusi / Lähivertailuja [Close Comparisons] \\ kaivapa@tlu.ee
}

Keywords: cross-linguistic influence, Estonian, Finnish, inflectional morphology, perceived cross-linguistic similarity, second language acquisition

Most SLA theories and models have recognised cross-linguistic influence (CLI) as an important or even the major factor determining the second language acquisition, which, in interaction with other factors, determines the likelihood of the transferability of a given structure in a given context. Interlingual identifications made by learners between the first (L1) or formerly learned (Ln) and target language (TL) enable both positive and negative transfer from the L1/Ln, depending on the learners' perceptions of the convergence or divergence of the L1/Ln and TL patterns. However, largely due to the visibility of non-target like language usage, the majority of studies on the CLI have focused on the negative outcomes of the issue or dealt with the CLI without separately tackling the positive and negative influence. In closely related languages like Finnish and Estonian with their rich inflectional morphology, the L1 influence is clearly seen in bound morphology, and its outcomes are considerably more often positive than negative.

The paper aims to explore how and why learners' perceptions of similarity do or do not get realised as positive CLI in inflectional morphology, on the basis of the following two databases: 1) thinking aloud protocols and retrospective interviews on an experimental inflection test of Estonian high school students learning Finnish as a foreign language; 2) longitudinal video-taped data of Estonian primary school children learning Finnish as a second language in a preparatory class.

The results indicate that both second and foreign language learners benefit from similar inflectional patterns when they perceive cross-linguistic similarity and then apply a pattern similar to L1 and TL. For foreign language learners, the two main reasons of rejecting the converging morphological patterns of L1 and TL are: 1) a psychological barrier, avoiding "too" similar patterns in Estonian and Finnish, causing the repetition of the pattern during analogical processing; 2) competition between analogical and rule-based production, which is supported by foreign language instruction. In learning closely related inflectional morphology, system learning for production precedes item learning for production both in second and foreign language learners. 